
The company has a strong cash position sion databases [with the exception of Incyte]," says Robert Burrow, director of corporate communication at Gene Logic. "Drug development may be a lot more glamorous, but you are looking at waiting 10-15 years for any revenue."

To date, Incyte has also shrugged off pressure to move into drug development. and could instead partner with a firm that can turn drugs into medicines, such as an antibody developer. Roy Whitfield, Incyte's CEO, says that Incyte's long-term prospects are pro-
The potential of the sector is considerably overestimated and many genomics companies may need to shift up another gear to survive. "low-volume and low-profit-margin products." However, gene-based diagnostic kits, such as those sold by Myriad Genetics, could offer much more profitable products that will play an integral role in personalized healthcare-the healthcare market of the future.

Meanwhile, Lehman analysts say that companies with the greatest potential are those that can offer "enabling technologies"- those that will impact on target identification and validation such as functional genomics and proteomics, or assist in the selection of new chemical entities. However, the Lehman-McKinsey tected by royaltybearing agreements with most major drug companies. However, these will not kick in for many years, says Lehman's Dougherty, and Incyte is currently dependent on its genomics-derived products.

One potential high-growth area could be diagnostics, an area that Toth says has been an "unattractive" place for investors with

Liz Fletcher, New York report concludes that existing technologies in these areas will have just moderate impact on drug discovery and that the "highest value will be gained from technologies that are currently in a fledgling state." Such technologies include protein-protein interaction identification and SNP profiling.

\section{Nasdaq restructures biotech index}

0 n January 23, 127 biotechnology companies with stock floated on the Nasdaq national market were unceremoniously dropped from that exchange's biotechnology index (IXBT), as Nasdaq implemented quantitative inclusion criteria in an effort to streamline the index. Analysts expect the share price of companies listed to reflect anticipated institutional investment in the new index, which some say is now a more stable version of the industry.

Companies with smaller market capitalizations have been weeded out in preparation for the launch of several financial products that track the index. The first to emerge will be the Barclay's Global Investments new exchange traded fund called the iShares Nasdaq Biotechnology Index Fund, due to launch in mid February. Barclays says the new iShares fund will allow investors to purchase an array of stocks akin to investing in a mutual fundin this case each company tracked by the IXBT-but investors will be able to trade shares as if it were an individual stock. Such products are expected to be popular as the old all-inclusive IXBT posted a $23 \%$ positive return in 2000 , compared to a nearly $40 \%$ loss turned in by the Nasdaq Composite Index.

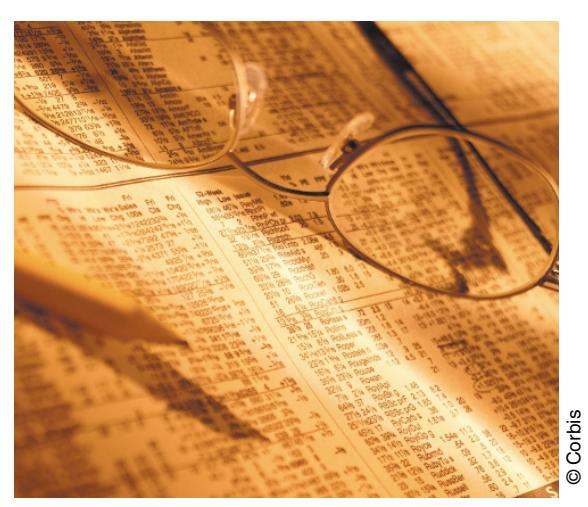

Companies with smaller market capitalizations have been weeded out in preparation for the launch of several financial products that track the index.

To be included in the new IXBT, each company must have a stock price greater than $\$ 10$ and a market capitalization greater than $\$ 200$ million. Average daily trading volume must be upwards of 100,000 shares, and companies must have been trading on the exchange for at least six months. And, much as before, each member must be "primarily engaged in using biomedical research for the discovery or development of novel treat- ments and cures for human disease," according to Nasdaq documents. The new index will be revised semiannually in May and November, using market data from March and September.

As a result of these requirements, the index has been reduced from 202 listings to 76. Only one-Luminex (Austin, TX), which develops bioassay technologies to speed drug discovery-was added. "It is a nice honor to stand out like that," says Mark Chandler, chair and CEO of Luminex, which floated in March 2000. "Being included in an index like that does reflect investor acceptance and market acceptance for your goods or services. It's a good boon to the company."

Indeed, the share price of 72 of the 76 "chosen" companies traded up on the news of the index, according to BioCentury. Companies remaining on the index range from the well-established, such as Amgen (Thousand Oaks, CA) and Genzyme General (Framingham, MA), to those with smaller market capitalizations such as Abgenix (Fremont, CA) and CuraGen (New Haven, CT). "We're very pleased to remain included," says Jennifer LaVin, senior director of corporate communications for novel antibiotics developer Cubist Pharmaceuticals (Cambridge, MA), which also remains on the index. "The new criteria make it more of an investment quality index."

Luminex's Chandler notes that of the 76 component companies there isn't one particular business plan or therapeutic area that dominates, and says that the new group of companies reflects the efficiency of market forces: If every company was part of the index, he says, it would not reflect those that have gained most of the market's interest.

Analysts agree, saying the new IXBT should be more stable. "There were a lot of walking wounded in the old index," says Robertson Stephens (New York) analyst Michael King. "I think now it's a good industry indicator-much more representative now than it was before."

Companies no longer listed on IXBT include small-molecule drug play BioCryst Pharmaceuticals (Birmingham, AL) and gene therapy firm Targeted Genetics (Seattle, WA), which have market capitalizations of \$127.1 million and \$263.1 million, respectively. Being dropped from the index seemed to have little effect on share price, however, although both are trading over $20 \%$ down from the previous quarter. As King says, while making the index for some may be an added bonus, "in the long run what counts is having solid fundamentals."

Christopher Morrison, New York 